\title{
Intermédialités
}

Histoire et théorie des arts, des lettres et des techniques

Intermediality

History and Theory of the Arts, Literature and Technologies

\section{The Disappearing Medium: Remarks on Language in Translation}

\section{George Varsos}

Numéro 10, automne 2007

Disparaître

Disappearing

URI : https://id.erudit.org/iderudit/1005559ar

DOI : https://doi.org/10.7202/1005559ar

Aller au sommaire du numéro

Éditeur(s)

Centre de recherche sur l'intermédialité

ISSN

1705-8546 (imprimé)

1920-3136 (numérique)

Découvrir la revue

Citer cet article

Varsos, G. (2007). The Disappearing Medium: Remarks on Language in

Translation. Intermédialités / Intermediality, (10), 165-179.

https://doi.org/10.7202/1005559ar
Résumé de l'article

Le texte concerne les incidences de la disparition de la langue d'un texte original, dans le cas de la traduction littéraire. Il commence par un rappel de la problématique élaborée, à cet égard, par la critique actuelle de l'appropriation ethnocentrique de l'original par la langue d'arrivée. Il examine, par la suite, les présupposés théoriques de cette critique, en insistant sur les différentes

manières dont les rapports entre langue et culture sont traités par la théorie de la traduction du romantisme allemand et par celle de Walter Benjamin. 


\title{
The Disappearing Medium: Remarks on Language in Translation
}

\author{
George Varsos
}

n translation studies, there is an insightful critique of what is frequently considered the dominant tradition of literary translation in the West. Said tradition favours methods that aim to produce "fluently" readable texts, smoothly integrated into the established literary modes of the target language. Specifically, translation must avoid archaism and jargon, as well as idioms or otherwise foreign syntax; it should clarify what remains obscure and attenuate what is rhetorically strange in the original, smoothing over disparities or inconsistencies. In so doing, however, it risks eliding not only specificities of the original text, but also the very fact that a different language is at stake in the process. Antoine Berman qualifies this type of translation as "ethnocentric," while Lawrence Venuti emphatically denounces the political implications of what he identifies as the normative "invisibility" of the translator. The "forcible replacement of the linguistic and cultural difference of the foreign text with a text that will be intelligible to the target-language reader,"2 writes Venuti, inheres within the construction of state-national identities and is concomitant with the hegemony of English in the global order of today. With respect to a poetics of translation, an opposition is drawn between strategies that are "domesticating" and those that are "estranging" or "foreignizing," as Venuti prefers. 3 Friedrich Hölderlin and Ezra Pound are often cited as paradigms of the latter, in that they allow their work to be drastically marked by, to bear visible traces of, the linguistic shift. In both their cases,

To Lili Florakas, my grandmother (Apeiranthos, 1910 - Montreal, 2007)

1. Antoine Berman, La traduction et la lettre, ou l'Auberge du lointain, Paris, Éditions du Seuil, coll. "Lordre philosophique”, 1999, p. 26 and following.

2. Lawrence Venuti, The Translator's Invisibility, London \& New York, Routledge, coll. “Translation studies”, 1995, p. 18.

3. The terms are those of Venuti, in his Invisibility, p. 20 and following. 
this shift is largely historical, from an ancient or medieval to a modern language. 4 More recent studies 5 have focused on the underlying tension between domesticating and estranging strategies in cases involving, on the one hand, languages such as English or French and, on the other, living languages deemed marginal with respect to hegemonic Western ones. ${ }^{6}$ The question of the degree and mode of correlation between the poetics and politics of translation remains, of course, both delicate and intricate. Equally so, is the underlying theoretical issue of how language relates to history and culture, which I would like address.

The normative invisibility of the translator stipulates that, as the language of the original is supplanted, the linguistic materiality of the original should not only disappear but should do so entirely: both the signifying mechanism of the original and the reading experience of it is swept aside, leaving a putative transposable signified content presumably more or less intact. Critique of this premise,

4. Translations of Homer can give us a tangible sense of differing translation strategies. Compare the opening of Ezra Pound's "Canto I" to the translation of the corresponding passage of The Odyssey (Book XI) by Allen Mandelbaum. Pound gives us his noted agrammatical beginning, broken pentameter and overall archaic tone: "And then went down to the ship, / Set keel to breakers, forth on the godly sea, and / We set up mast and sail on that swart ship, / Bore sheep aboard her, and our bodies also/ Heavy with weeping, and winds from sternward / Bore us out onward with bellying canvas, / Circe's this craft, the trim-coifed goddess." (The Cantos, London, Faber and Faber, 1986, p. 3). Mandelbaum's writing is clearly domesticating in certain respects, especially at the level of rhythm: "We reached the shore and ship. We drew our craft / down to the gleaming sea. We stepped the mast / and set our sail, embarked our sheep; downcast, / in tears, we went aboard. Then fair-haired Circë, / the awe some goddess with a human voice, / sent forth a friend who favored us, a wind / that swelled our sail and spurred our ship's dark prow." (The Odyssey of Homer, Berkeley, University of California Press, 1990, p. 217).

5. See Sandra Bermann and Michael Wood (eds), Nation, Language and the Ethics of Translation, Princeton, Princeton University Press, coll. "Translation-transnation," 2005.

6. Consider, for instance, translations of $18^{\text {th }}$ century Bengali poetry associated with the figural tradition of the "motherly" goddess, Kali. Gayatri Spivak compares her own foreignizing English version with an earlier domesticating French one. In Spivak's English: "Mind, why footloose, from mother? / Mind mine, think power, for freedom's dower, bind bower with love-rope / in time, mind, you minded not your blasted lot." The French version from the twenties: "Pourquoi as-tu, mon âme, délaissé les pieds de Mâ? / Ô esprit, médite Shokti, tu obtiendras ta délivrance. / Attache-les, ces pieds saints, avec la corde de la dévotion." (Gayatri Chakravorty Spivak, "The politics of translation," in Lawrence Venuti (ed.), The Translation Studies Reader, New York and London, Routledge, 2000, p. 374). 
be it from a political or a poetic point of view, echoes an acute understanding of the crucial role of the signifier with respect to the signified: the disappearance of the linguistic medium, when passing from one language to another, is an event that must be acknowledged as such and taken into account, both practically and theoretically. The problem is not simply that of the distinct signifying role which specific lexical units or grammatical mechanisms play in one language or another-and with which every translation somewhat contends. There emerges, furthermore, the issue of whether the overall linguistic identity of the original has some specific character or significance that affects the linguistic shift and marks or should mark the translated text: is there something in a language which runs through its established means and techniques of eloquence, its diverse versions or usages, its modalities and rhythms of change, and which presents a distinct challenge to translation, even when specific problems of vocabulary, grammar and rhetoric in a given text have been adequately addressed?

Translation thus kindles awareness of the fact that at work are also individual languages: structural wholes of uncertain nature and implication. Samuel Weber has recently questioned the pertinence of terms like "natural" or "national" with regard to the notion of individual languages, further remarking that:

[the] difficulty of finding a generic term that would accurately designate the class to which individual languages belong is indicative of the larger problem of determining the principles that give those languages their relative unity or coherence-assuming, that is, that such principles really exist. ${ }^{7}$

Weber herein discloses one of the blind spots among the insights of critiques of ethnocentric translation: the latter often take the nature of individual languages for granted, failing to probe systematically the corresponding theoretical difficulties. To be sure, certain basic premises are routinely acknowledged in this respect. Venuti, for instance, specifies that "the foreign in foreignizing translation is not a transparent representation of an essence that resides in the foreign text and is valuable in itself, but a strategic construction whose value is contingent on the current target-language situation." ${ }^{8}$ More generally, we are put on our guard against the ever-present temptation of "essentialism" or invited to rethink translation "in historical and temporal terms rather than in ontological and spatial

7. Samuel Weber, "A Touch of Translation: On Walter Benjamin's “The Task of the Translator," in Sandra Bermann and Michel Wood (eds), Nation, Language and the Ethics of Translation, p. 66.

8. Lawrence Venuti, Invisibility, p. 20. 
ones."9 At times, however, there is a tendency to correlate language and culture on grounds of categories warranted by rather crude ontological assumptions. Linguistic difference is then readily seen as synonymous with radical cultural otherness or foreignness: "A translated text", Venuti claims, "should be the site where a different culture emerges, where a reader gets a glimpse of a cultural other, and resistancy [reminds the reader of] the unabridgeable gaps between cultures." ${ }^{10}$ Linguistic homogeneity, along with resistance to translation, tends to be assumed as an attribute of all cultures as in the following postulate of Berman:

[...] toute culture résiste à la traduction, même si elle a besoin essentiellement de celleci. La visée même de la traduction - ouvrir au niveau de l'écrit un certain rapport à l'Autre, féconder le Propre par la médiation de l'Étrange - heurte de front la structure ethnocentrique de toute culture, ou cette espèce de narcissisme qui fait que toute société voudrait être un tout pur et non mélangée. Dans la traduction il y a quelque chose de la violence du métissage."

In order to investigate effectively the implications of the disappearance of a language in translation, along with the correlative issue of the nature of individual languages, we need to revisit the ways in which relations between linguistic and cultural identity are conceived. This presupposes the critique of the very juxtaposition of historical and ontological perspectives. I would like, very briefly in the following pages, to examine two lines of inquiry into the matter, both of which serve as fundamental references in translation studies. The first derives from those early $19^{\text {th }}$-century German thinkers, usually associated with Romanticism, who have broached the disappearance of a language, in translation, as a practical and theoretical problem and elaborated the modern distinction between domesticating and foreignizing translation, championing the latter. I refer, specifically, to Wilhelm von Humboldt and Friedrich Schleiermacher and would like to draw attention to the ontological premises subtending their key concept of historical culture (Bildung) and its connection to language.

The second line of inquiry is the one of Walter Benjamin, an equally influential but perhaps more intriguing advocate of estranging translation techniques. His theory of translation is in many respects a stepping-stone in the elaboration of a theory of languages as individual wholes. His approach presupposes, in a sense, the insights of German Romanticism, but it also drastically destabilizes their

9. Sandra Bermann, "Introduction," in Sandra Bermann and Michel Wood (eds.), Nation, Language and the Ethics of Translation, p. 6.

10. Lawrence Venuti, Invisibility, p. 306.

11. Antoine Berman, L'épreuve de l'étranger: Culture et traduction dans l'Allemagne romantique, Paris, Éditions Gallimard, coll. "Les essais", 1984, p. 16. 
claims, especially those concerning the link between language and culture. At the same time, he insists on critically reconfigured historical but also ontological problematics without in any sense discarding the pertinence of the latter.

My comparison of Benjamin and German Romantic thinkers is, indeed, based largely on ontological grounds, as it involves the notion of form, which is crucially central in both. By form, I mean a philosophical notion that pertains, as the Oxford English Dictionary explicates, to the essential principle of a thing-to the principle that allows the thing to emerge or manifest itself as a determinate kind of being and thus to appear as phenomenon. Considerations of form in this sense have often been understood to close discussion of what is essentially at stake with phenomena that emerge or disappear-in our case, linguistic phenomena. However, the question of form can also be raised as an aporia that keeps the discussion ever open and indeterminate-the discussion, that is, of whether and in what way languages qua individual wholes constitute significant components of given textual or other kinds of linguistic formations.

A passage from the beginning of Aristotle's On Interpretation sets the basic terms with which Humboldt configures his idea of language. The passage identifies language as an exemplary instance of mediation; it explains also how elusive its mediating function can be, presupposing as it does successive instances of transformation:

Now spoken words [ta en te phone] are symbols [symbola] of affections in the soul, and written marks symbols of spoken sounds. And just as written marks are not the same for all men, neither are spoken sounds. But what these are in the first place signs [semeia] of-affections of the soul-are the same for all; and what these affections are likenesses [omoiomata] of-actual things [pragmata]-are also the same. $(16 a 3)^{12}$

There is, quite clearly, the image of a chain here, the links of which, however, are not all of the same nature. Through an initial mediation (which, we presume, is that of the senses) things (pragmata) affect the soul. Their marks are simulacra (omoiomata), that is, mental images bearing their likeness - so much so that both things and mental images can be assumed to be the same for all. The relation changes drastically, however, as we pass, via a second mediation (that of language), from mental images to things of the voice [ta en te phone]. This time the link is of a symbolic (symbola) or semiotic (semeia) nature, such that relative stability or universality gives way to indeterminacy and variation. Now, Humboldt's conception of language presupposes this Aristotelian schema in a decidedly Kant-

12. Aristotle, Categories and De Interpretatione, trans. by J. L. Ackrill, Oxford, Clarendon Press, coll. "Clarendon Aristotle Series", 1963, p. 43. 
ian inflection. He understands affections of the soul to involve a complex correlation between, on the one hand, elementary forms of intuitive experience and, on the other, forms elaborated via categories of conceptual understanding. Imagination intervenes as an effective but also intricate link between the two. Language, in turn, emerges from within the interplay of imagination and understanding, and possesses, as such, a characteristically dual articulation: its basic elements have an imagistic or iconic affinity, not to things themselves but to forms given by experience, as well as a more abstract component, closer to the status of signs associated with conceptual elaboration. At the level of its most fundamental and general structures, language is thus close enough to the basic shemas of human experience and concepts of rational understanding to acquire a universal dimension; but it is also decisively linked to the culturally conditioned work of imagination, as the latter stimulates and enacts the relations between experience and understanding. Language is thus composed of sounds which imitate universal forms of human reason but only by culturally configuring them while transpose them to a state of sustained ideational dissolution:

All signs of language are symbols [Symbole], not the things themselves, not signs [Zeichen] agreed on, but sounds which find themselves, through the mind in which they originate and keep originating, in a real and, so to speak, mystical connection with the things and concepts they represent; which contain the objects of reality dissolved, as it were, in ideas [aufgelöst in Ideen]. These symbols can be changed, defined, separated and united in a manner for which no limit can be imagined. A higher, deeper or more tender sense [Sinn] can may imputed to these symbols, which happens only if one thinks, expresses, receives, and represents them in a certain way; and so language is heightened to a nobler sense, extended into a medium which shapes in more complex ways, without any really noticeable change. ${ }^{13}$

The determinant link can thus be established, as Humboldt will do, between individual languages and specific modes of culture (Bildung) in history. The distinct ontological premises of this linkage are echoed in the metaphorical use of

13. Wilhelm von Humboldt, "A theory of translation," p. 41-42, André Lefevere (ed.), Translating Literature: the German Tradition, Amsterdam, Van Gorcum, 1977, p. 40-45. The text comes from Humbold's introduction to his translation of Aeschylus' Agamemnon (Einleitung zu Agamemnon, 1816). I have consulted the original in the bilingual edition of: Wilhelm von Humboldt, Sur le caractère national des langues et autres écrits sur le langage, trans. by Denis Thouard, Paris, Éditions du Seuil, coll. "Points. Essais," 2000, p. 33-47. This edition contains texts and fragments dating form 1816 to 1824. On the relations between Humboldt and the Kantian tradition, as well as for a series of insightful approaches to different aspects of Humboldtian linguistics, see Jürgen Trabant, Humboldt ou le sens du langage, Liège, Mardaga, coll. "Philosophie et langage," 1992. 
the natural organism which configures the structure and dynamics of collective historical identities:

The human species is a natural plant, just like the species of lions and elephants. Its different tribes and nations are natural products like races of Arabic and Island horses. There is, however, this singular difference: within the very seeds of their culture [Bildung] the idea of language and freedom finds a more or less favourable soil and connects to forces which are manifested to us in no other way. Any singular individual is an individual with respect to its nation in the same way that a leaf is one with respect to its tree; and degrees of individuality can thus extend for nation to people and form there to race and to the human species. ${ }^{14}$

Each singular individual could very well be seen as having its own culture and language, as could the human species itself, as an individual whole. The most crucial connection is that established between individual languages and national communities: "Fundamentally [...] in its identity to the thought which is made possible by it, language is the nation itself, it is properly speaking the nation [die Nation selbst, und recht eigentlich die Nation]." 15 What is most important, however, is that the essence of an individual language is seen as concomitant with the essence of a cultural anthropological entity-which could be situated at any level of organisation of the different species of human life. It is, in a sense, the essence of an essence: the "unmediated breath of an organic essence [unmittelbarer Aushauch eines organischen Wesens]."16

This essence of languages as totalities corresponds to their internal linguistic form (innere Sprachform), a pivotal notion in Humboldtian linguistics. On the basis of this Sprachform, every language reproduces itself incessantly and is constantly present in its entirety and complete unity in forms that range from elementary grammatical rules and simple phrases to larger linguistic constructs. It is both moulded in accordance with a corresponding human culture and moulds the evolution of this culture through history, all the while engaging its distinct

14. Wilhelm von Humboldt, "Betrachtungen über die Weltgeschichte", p. 568-569, in Werke in fünf Bänden, I, Andreas Flitner and Klaus Giel (eds), Darmstadt, Wissenschaftliche Buchgeselschaft, 1980, p. 567-577. The lecture dates from around 1820. I translate.

15. Wilhelm von Humboldt, "Ueber den Einfluss des verschiedenen Charakters der Sprachen auf Literatur und Geistesbildung." p. 124, in Humboldt, Sur le caractère national des langues, p. 124.

16. Wilhelm von Humboldt, "Ueber das vergleichende Sprachstudium in Beziehung auf die verschiedenen Epochen der Sprachentwicklung,” p. 68, in Humboldt, Sur le caractère national des langues, p. 64-111. 
perspective on the world (Weltansicht). The Sprachform is not envisaged, however, as a static or homogeneous mental structure or worldview. Rather, it is a kind of energy (the Greek energeia is Humboldt's term of choice) that sustains dialogical dynamics proper to the language concerned, throughout its variation and evolution. As such, it runs through all specific literary genres and works in which the specific "character" of a language develops. However, it also allows for the Humboldtian postulate according to which all languages ideally converge on the common ground of the universality of human reason in world history.

It is from the standpoint of their internal forms that languages become the object of comparative study for Humboldt. The specific grounds and criteria for such comparison, an issue to which he persistently returns in his writings, bring up the question of what it is we are dealing with when we speak of the individual nature of a language. There is a decisive tension, in this respect, between, on the one hand, the typological and inescapably prejudicial distinction between poor and rich (or primitive and cultivated) languages and, on the other, the awareness that linguistic entities may be incommensurate and therefore scarcely comparable.

We can suggest that Humboldt tends towards a kind of cultural historicism which is very close to August Wolf's contemporaneous reformulation of the philological paradigm and to the parallel emergence and development of modern historical hermeneutics. The workings of "living" languages are seen as sustaining the development of corresponding national or other cultural entities, also enabling intercultural relations; while the written traces of "dead" languages allow the knowledge of ancient cultures according to their position in historical temporality. Literary texts provide the most salient manifestations of a language and its culture. Their traces, often inadequate, worn out or obscure are subject, as such, to philological criticism and restoration in accordance with the principles of their historical, that is indistinguishably linguistic and cultural identity. As for translation, it hereby acquires a theoretically contentious significance, since its task spans not simply linguistic differences but boundaries separating distinct organisms. The disappearance of a language in the substitution of the original text in literary translation turns into a singular theoretical and practical concern, to the precise degree that it risks entailing the disappearance of a historically positioned form of human life-either of its active presence, when living languages are involved, or of its memory, when texts of dead languages are at stake.

In the introduction to his translation of Aeschylus' Agamemnon, Humboldt explains why translation can be considered, in certain respects, impossible. He goes on to add that, in its inevitability, translation should somehow echo the foreign character of the original, avoiding all the while making the language 
resound awkwardly with strangeness: translation is successful as long as one senses "nicht die Fremdheit sondern das Fremde."17 However, it is Friedrich Schleiermacher, the theoretician of modern hermeneutics, who is most often credited as having provided us, in his essay on various methods of translation, with a typically modern formulation of the dilemma surrounding domesticating and foreignizing translation techniques:

In my opinion there are only two [roads]. Either the translator leaved the author in peace, as much as possible, and moves the reader towards him; or he leaves the reader in peace, as much as possible, and moves the author towards him. The two roads are so completely separate from each other that one or the other must be followed as closely as possible, and that a highly unreliable result would proceed from any mixture, so that it is to be feared that author and reader would not meet at all..$^{18}$

A strictly linear conception of temporality is what makes the two paradigms incompatible and the choice between them inevitable: the translator must choose between moving backward or forward in time. Schleiermacher opts, in principle, for the first of the two. The translated text should transmit to the reader not simply a vague feeling of linguistic foreignness, but a specific sense of determined otherness (etwas bestimmtem anderm klingen). ${ }^{19}$ It should allow him to distinguish between translations of antique and modern texts, as well as among different modern languages and their corresponding cultures.

It is entirely characteristic of cultural historicism that estranging translation strategies are considered preferable, though they risk turning translation into what Schleirmacher admits is a somewhat mad enterprise (thörichtes Unterneh$m e n^{20}$ ) or even an unnatural one: the translator resembling "those parents who abandon their children to acrobats, of bending his mother tongue to foreign and unnatural dislocations instead of skilfully exercising it in its own natural gymnastics." ${ }^{21}$ Indeed, the idea of distinct cultural entities in history entails, for

17. Wilhelm von Humboldt, "Einleitung zu Agamemnon" p. 39, in Humboldt, Sur le caractère national des langues.

18. Friedrich Schleiermacher, "On the Different Methods of Translating," p. 74, André Lefevere (ed.), Translating Literature, p. 67-89. Schleirmacher’s "Über dies Verschiedenen Methoden des Uebersezens," was originally given as a conference in 1913. I have consulted the original essay in the bilingual edition of: Friedrich Schleiermacher, Des différentes méthodes du traduire, trans. Antoine Berman and Christian Berner, Paris, Éditions du Seuil, coll. "Points. Essais," 1985.

19. See Friedrich Schleiermacher, Des différentes méthodes du traduire, p. 66.

20. See Friedrich Schleiermacher, Des différentes méthodes du traduire, p. 44.

21. Friedrich Schleiermacher, "On the Different Methods of Translating", p. 79. 
Schleiermacher, the firm principle of a single national culture and language for each human group or individual: "Just as a man must decide to belong to one country, just so he must adhere to one language, or he will float without any bearings above an unpleasant middle ground."22

One of the reasons Walter Benjamin's work remains acutely relevant today, lies in the fact that its critique of Romantic historicism stands at odds with dominant trends in contemporary translation theory. Instead of casting ontology aside, in favour of the notion of culture, Benjamin persists in coupling historical and idiosyncratic ontological problematics, meanwhile disengaging the idea of language from that of culture. In doing so, as I will try to show, he approaches translation from a standpoint that is not predominantly that of cultural difference or of foreignness as opposed to domestication.

In his early essay on the task of the translator, Benjamin explicitly connects the notion of translation to that of individual languages as such, in their totality or as language-wholes: translation pertains "auf die Sprache als solche, ihre Totalität" or "auf eine Sprache im ganzen."23 It is thus all the more intriguing that he never recurs, in this regard, to schemas or thematics involving relations between a given language and a national culture, a world-perspective or the spirit of a people; and that, furthermore, he has no systematic recourse to the Romantic notion of Bildung as a theoretical concept or analytical tool. What is also quite characteristic of his approach is that he explicitly discards the idea that individual languages would be foreign to each other:

As for the posited innermost kinship of languages, it is marked by a peculiar convergence. This special kinship holds because languages are not strangers to one another [einander nicht fremd], but are, a priori and apart from all historical relationships [von allen historischen Beziehungen abgesehen], interrelated [verwandt] in what they want to express. ${ }^{24}$

22. Friedrich Schleiermacher, "On the Different Methods of Translating", p. 84.

23. Walter Benjamin, "Die Aufgabe des Übersetzers," p. 16, in Walter Benjamin, Gesammelte Schriften, Rolf Tiedemann and Herman Schweppenhäuser (eds), Frankfurt am Main, Suhrkamp Verlag, 1972-1989, Vol. IV. 1, p. 9-21. Henceforth, references to this text will be indicated by the initials "AU," followed by the page numbers, and placed between parentheses in the body of the text.

24. Walter Benjamin, "The Task of the Translator," trans. Harry Zohn, in Walter Benjamin, Selected Writings, Marcus Bullock and Michael W. Jennings (eds.), Cambridge MA, Belknap Press / Harvard University Press, 1996, Vol. 1, p. 255. Henceforth, references to this text will be indicated by the initials "TT," followed by the page numbers, and placed between parentheses in the body of the text. The German quotation in this passage comes from $\mathrm{AU}$, p. 12. 
The idea of the interrelation or convergence of different languages, equally present in Humboldt but only as a rather tentative or abstract hypothesis, assumes crucial importance in Benjamin. It allows the opening of a field of inquiry parallel to the study of given historical conditions; it is concomitant with the idea that languages, as individual wholes, cannot be rightly understood as entirely correlative with the historically determined cultural traits of their speakers' modes of life-they exceed, in some sense, the lives of their speakers. From this point of view language-wholes constitute what Benjamin identifies as distinct modes of intending or indexing (Art des Meinens) pure language (reine Sprache):

Rather, all suprahistorical kinship [überhistorische Verwandschaft] between languages consists in this: in every one of them as a whole, one and the same thing is meant. Yet this one thing is achievable not by any single language but only by the totality of their intentions supplementing one another: the pure language. (ТT, p. $257 ; \mathrm{AU}$, p. 13 )

The concept of pure language springs from arguments elaborated in Benjamin's earlier essay on human language. ${ }^{25}$ The semiotic character of any human language, directly linked as it is to cultural parameters of life and practices of communication, is always coupled with a non-semiotic or pure dimension that cultural conditions cannot contain. This dimension, Benjamin claims, concerns languages as individual wholes and pertains to the very fact of human-linguistic intercourse. Language at this level communicates nothing but the essence of humanness in its communicative and communicable dimension: it bespeaks the singular capacity of humans to identify things according to different modalities of naming. This idea removes us from the confines of Aristotelian "affections of the soul," and orients us toward an inquiry quite different from the one Humboldt traces in his own conception of the dual articulation of language. Benjamin's approach allows, of course, for the fact that all linguistic practices, including literary works, are concomitant with the cultural patterns of their historical emergence and life while also involving universally human basic forms of conceptual understanding. It also suggests, however, that linguistic constructs, especially literary formations, involve, at the level of their language as a whole, the enigmatic form of a purely human-linguistic essence, irreducible to the workings of human mind and experience. That form elucidates a perspective which,

25. I am referring to the 1916 text addressed to Gershom Scholem and entitled "Über Sprache überhaupt und über die Sprache des Menschen," published in Gesammelte Schriften, Vol. II.1, p. 140-157. English translation, "On Language as Such and on the Language of Man," trans. Edmund Jephcott, in Benjamin, Selected Writings, p. 62-74. 
although not historical in the current sense of the term, is neither ahistorical, and can indeed be better qualified as over or supra-historical. It undoes, to some extent, the pertinence of forms proper to cultural conditioning. So, while it has a lot to do with the specificity of all human life as essentially linguistic, it is irreducible to given historical circumstances and modes of semiosis, which pertain to attributes of linguistic formations that could be qualified as contingent.

The notion of form is, indeed, paramount in Benjamin's essay on translation. There, he tellingly employs terms like Gebilde or Geformte-which connote form and can best be rendered as formation-over that of text. It is also from a notion of form that Benjamin broaches the issue of translation: "Übersetzung ist eine Form," or "translation is a form," he insists, the key to which resides in how the original is itself translatable. That claim is substantiated by remarks on how translatability (Übersetzbarkeit) is an attribute of the original literary work which establishes the law (Gesetz) of the form concerned, to the degree that and on account of its essence, it claims or calls for translation: "ob es seinem Wesen nach Übersetzung zulasse," (AU, p. 9-10). The determinant role of the original does not, however, imply a philological or hermeneutic turn to the cultural conditions of its emergence. Upon translation, the language of the original performs a more complex gesture: on the one hand, and as a matter of course, it links its textual formation to the cultural conditions of its genesis; on the other, it disengages it from them and opens it onto what Benjamin calls its "overlife" or "survival" (Überleben or Fortleben). The different modes of conservation, reproduction and circulation of a literary formation, along with its eventual translations, do not constitute mere duplicates or copies of its original instance, more or less faithful or adequate as the case may be: they deploy different aspects of the corresponding linguistic entity, the essence of which remains necessarily incomplete and indeterminate or uncertain in time, quite independently from the cultural parameters of its emergence and initial cycle of life. This does not mean that the issue of history is effaced; on the contrary, it is reinstated via the critique of historicist modes of understanding the dynamics and stakes of historical temporality. Translation allows for crucial insights into historicity, to the precise extent that it highlights the partial disengagement of the idea of language from that of culture and stimulates an interplay between the two facets of the question of form raised with respect to literary texts - that of human-linguistic essence and that of cultural contingency. ${ }^{26}$

26. Tejaswini Niranjana has well presented the argument of why and how Benjamin's approach to translation should indeed be read as directly involving the claim of a non- 
Benjamin explicitly privileges strategies of translation which do indeed remind us of "foreignizing" methods: close rendering of the syntax of the original, bringing isolated words to the fore, using literal interlinear translation as a model. But this is where the term "estranging" proves entirely more accurate: it would be erroneous to consider the techniques advocated by Benjamin as in any way complicit with notions of cultural identity and otherness, involving the dichotomy of domesticity and foreignness. We are, perhaps one could say, paradoxically closer, in a somehow reversed or transposed way, to Brechtian notions of distancing or estrangement. Benjaminian translation brings to the fore, not so much the relation between two languages culturally foreign to each other, but rather the tension, running through both languages, between their semiotic and their non-semiotic components, between their culturally determined identities and their modes of indexing pure language and suspending cultural affiliation. Through its estranging tonalities, Benjaminian translation exposes the fact that while philologically restored text, culturally deciphered meaning, and hermeneutic dialogue are important, indeed crucial, they do not exhaust the overall significance of a literary formation. The task of translation diverges significantly from that of culturally informed study: the writing techniques destabilise the original as a signifying construct, in order to effectively address the question, however aporetic, of purely linguistic form, over and above the one of culturally determined meaning. The disappearance of the language of the original, far from simply stimulating acknowledgement of cultural otherness, is precisely what allows the emergence of this aporia to act as a stimulus to theoretical quest and practical artistry addressing the undoing of cultural conditioning: "A real translation is transparent; it does not cover the original, does not block its light, but allows the pure language, as though reinforced by its own medium, to shine upon the original all the more fully." (TT, p. 260) There is little here to suggest that the language of the translation echoes with foreignness of any kind. If strangeness there is, it is not that of a foreign language, but of language as such. Language, literary language in particular, proves to be the medium that, however closely connected to culturally determined semiosis, is also what delivers humans

historicist understanding of and approach to history. She tends to overlook the role, in this respect, of Benjamin's metaphysics. See "Politics and Poetics: De Man, Benjamin and the Task of the Translator," in Tejaswini Niranjana, Siting Translation: History, Poststructuralism and the Colonial Context, Berkeley, University of California Press, 1992, p. 110-140. 
from cultural determinants. Recall the words of Paul de Man, caught as was in the aporia:

This movement of the original is a wandering, an errance, a kind of permanent exile if you wish, but it is not really an exile, for there is no homeland, nothing from which one has been exiled. Least of all is there a reine Sprache, a pure language, which does not exist except as a permanent disjunction which inhabits all languages as such, including and especially the language one calls one's own. What is to be one's own language is the most displaced, the most alienated of all. ${ }^{27}$

Benjamin's “The Task of the Translator" also provides a link between early texts (notably the "Prologue" to his study of the Trauerspiel ${ }^{28}$ ) and the unfinished labours of his Passagen-Werk - that is, between the metaphysics of form and more explicit problematics of history. Recall, in this regard, fragment $\mathrm{N}_{3.1}$ of the Passagen, which explicitly juxtaposes "Bild" (a notion which, here, comes very close not only to that of form but also to Breton's definition of the surrealist image) to categories of the human sciences (including, we may presume, the category of culture or Bildung). An image, with its historical index, could very well be the challenge presented by a given textual formation to the reader who ventures to discern and historically connect to its purely human-linguistic form:

These images are to be thought of entirely apart from the categories of the "human sciences," from so-called habitus, from style, and the like. For the historical index of the images not only says that they belong to a particular time; it says, above all, that they attain to legibility only at a particular time. And, indeed, this acceding "to legibility" constitutes a specific critical point in the movement at their interior. Every present day is determined by the images that are synchronic with it: each "now" [Jetzt] is the now of a particular recognisability. [...] It is not that what is past casts its light on what is present, or what is present its light on what is past; rather, image $[$ Bild] is that wherein what has been [das Gewesene] comes together in a flash with the now to form a constellation. ${ }^{29}$

27. Paul de Man, “Conclusions: Walter Benjamin's “The Task of the Translator," in Paul de Man, The Resistance to Theory, Minneapolis, University of Minnesota Press, coll. "Theory and History of Literature" 1982, p. 92.

28. See Walter Benjamin, "Epistemo-Critical Prologue," in The Origin of German Tragic Drama, trans. John Osborne, London, NLB, 1977, p. 27-56.

29. Walter Benjamin, The Arcades Project, Rolf Tiedemann (ed.), trans. Howard Eiland and Kevin McLaughlin, Cambridge, MA and London, Belknap Press / Harvard University Press, 1999, p. 462-463. For the German original see Gesammelte Schriften, Vol. 1, p. $57^{8}$. 
"Das Gewesene," the presently perfected remains of what has been, does not comply with becoming and is incompatible with the temporality of narration. It means termination rather than ending, interruption rather than closure, eventual closeness rather than established distance: the enigma of disappearance rather than the certainty of death. It is more akin to amorphous ruins piling up than to recognisable monuments. There is no predetermined course leading from perfected modes of having been human and alive to the prospect of a natural or otherwise proper deployment, and no present moment can be sheltered from the claim of remembrance addressed to it by such remains: any Jetzt is liable to be confronted with the challenge of a Gewesene that may crucially suspend confines of a cultural nature. A kind of history at odds with historicist premises is thus at work: figurative rather than narrative, dialectically arrested rather than temporally evolving. Current life turns historic, not because the consummation of its own past provides it with the depth of cultural continuity and the awareness of its identity, but because all disappeared pasts, however distant or close, risk inhabiting its field and permeating its ongoing momentum. Translation is that activity which puts into words not the foreignness of the past, but the disquieting familiarity of its presence.

Fragment $\mathrm{N}_{3.1}$ begins by disclaiming the phenomenological concept of essence and, more explicitly, the Heideggerian attempt to connect history to phenomenology. It is, indeed, a different kind of pertinence that Benjamin claims for the basic notions of metaphysics through his own use of terms like Gewesene or Bild. Compared to Benjamin's metaphysics of form, the Heideggerian quest for the foundational moments of historically distinct modes of being remains, in many respects, an eccentric way of sustaining historicist premises and containing the insights of an effectively critical ontology. For Heidegger, the moment of emergence holds the key to forms of deployment and concealment in time. Could it be that, for Benjamin, disappearance is what counts, detaching phenomena from forms of temporal flow? But that is an issue to which my remarks here can do no more than point. ${ }^{\circ}$

30. My thanks to Brian Neville with whom I have discussed the text at length and who, though fearful of domesticating my English, helped to lessen its most estranging locutions. 